\title{
Movements and Mortality of American White Pelicans Fledged in Three Montana Colonies
}

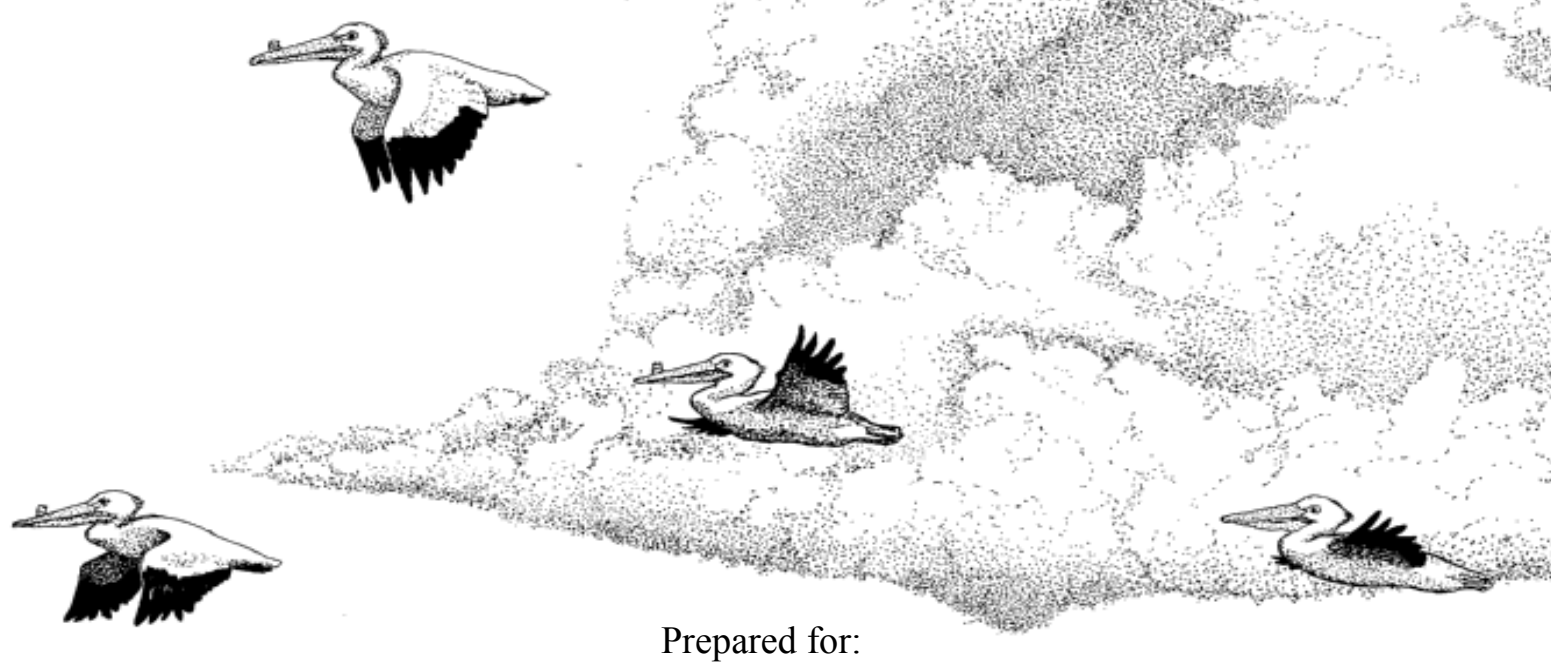

U.S. Fish and Wildlife Service Benton Lake National Wildlife Refuge

Prepared by:

Paul Hendricks and Robert F. Johnson

Montana Natural Heritage Program Natural Resource Information System Montana State Library

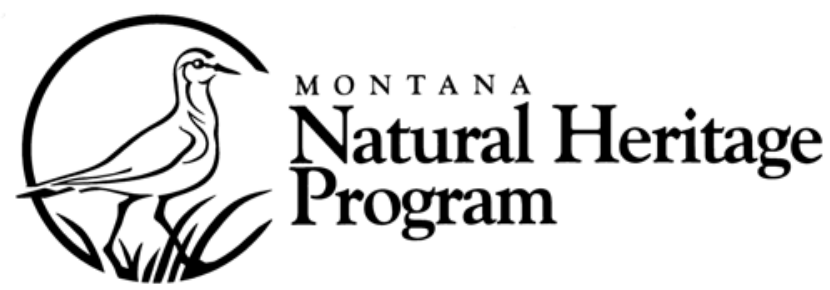




\title{
Movements and Mortality of American White Pelicans Fledged in Three Montana Colonies
}

\author{
Prepared for : \\ U.S. Fish and Wildlife Service \\ Benton Lake National Wildlife Refuge \\ 922 Bootlegger Trail \\ Great Falls, MT 59404-6133
}

Agreement \# 61510-0-0400

Prepared by:

Paul Hendricks and Robert F. Johnson
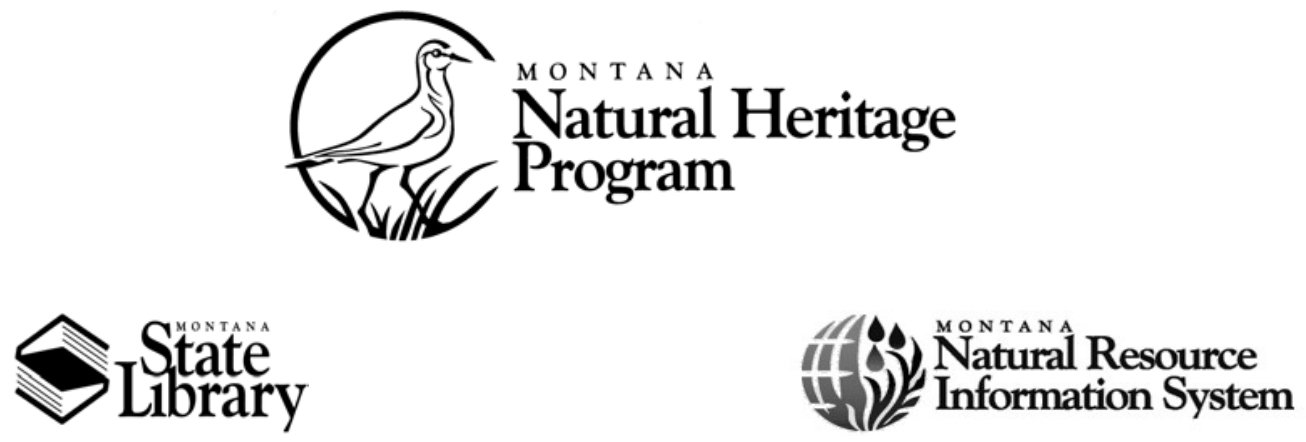

(C) 2002 Montana Natural Heritage Program

P.O. Box $201800 \bullet 1515$ East Sixth Ave • Helena, MT 59620-1800 • 406-444-3009

This document should be cited as follows:

Hendricks, P., and R. F. Johnson. 2002. Movements and mortality of American White Pelicans fledged in three Montana colonies. Report to the U.S. Fish and Wildlife Service. Montana Natural Heritage Program, Helena. 17 pp. 


\section{EXECUTIVE SUMMARY}

Montana is home to a significant number of breeding American White Pelicans (Pelecanus erythrorhynchos), a species of conservation concern with a global population breeding in fewer than 70 colonies. The four breeding colonies in Montana have grown to approximately 10,000 breeding pairs within the last ten years. Banding of juveniles has occurred at each colony at one time or another, yet band return data have never been examined to identify patterns in migratory movements and mortality that may affect management.

We analyzed data for 276 band recoveries of American White Pelican banded as juveniles at three Montana colonies east of the Continental Divide. The majority of non-Montana returns for the Bowdoin colony in far-eastern Montana indicated most pelicans migrated south and east to the Gulf of Mexico and eastern Mexico. Returns for the Canyon Ferry and Arod colonies near the Continental Divide showed a different migratory movement, with the majority of birds crossing the Divide and moving west and south to southern California and western Mexico. We found little evidence for movement of birds between Montana colonies, and only one case of a bird born in one Montana colony attempting to breed in another.

Overall mortality rates ranged from 30\% for Canyon Ferry and Bowdoin to 39\% for Arod; both Arod and Canyon Ferry had adult mortality rates $>35 \%$, which are unusually high for this species. Birds "found dead" of unknown causes accounted for 39.0-53.0\% of recoveries from all colonies. Shot birds accounted for $21.7 \%$ of returns for Bowdoin, whereas disease (botulism in particular) was the attributed mortality factor for $47.5 \%$ of Canyon Ferry returns and $34.3 \%$ of Arod Lakes' returns. The difference in significant mortality factors among the colonies can be attributed largely to differences in years when banding occurred and different colony migration patterns. Over $40 \%$ of the recoveries for the Arod and Canyon Ferry colonies were from the Salton Sea of California, which experienced a botulism outbreak in the late 1990's. Botulism affected all age classes, whereas shooting was more likely to affect juvenile pelicans (first- and second-year birds).

We conclude that there are two relatively distinct colony groupings of breeding pelicans in Montana: one (Canyon Ferry and Arod Lakes colonies) using the Intermountain West and Pacific flyways, and the other (Bowdoin, with the Medicine Lake colony) the Central and Mississippi flyways. However, a coordinated and simultaneous color-marking program at all Montana colonies would better document migratory movements, areas of non-breeding concentration, and the amount of inter-colony dispersal.

Conservation and management of the Montana colonies needs to include consideration of the distinctive flyway affiliations of the colonies and threats to habitat in areas where birds concentrate during the nonbreeding season, as well as threats to the individual breeding colonies themselves. A regional perspective is also desirable to coordinate management among colonies demonstrating intermixing of the breeding memberships. 


\section{ACKNOWLEDGEMENTS}

Field work in 2000 and production of this report was funded by a Challenge Cost-Share agreement between the U.S. Fish and Wildlife Service (USFWS), and the Montana Natural Heritage Program (MTNHP), which is part of the Montana State Library's Natural Resource Information System (NRIS).

Banding at the Arod Lakes and Canyon Ferry colonies was largely the result of volunteer efforts initiated in 1991 by Dave Genter and later co-supervised by Jim Reichel (both formerly with MTNHP) and conducted in cooperation with personnel at Benton Lake National Wildlife Refuge and Canyon Ferry Wildlife Management Area. We thank the many volunteers involved in six years of banding at these two colonies, especially Cedron Jones, Margaret Beer, Melony Bruhn, Kathy Jurist, Debbie Dover, Mike Schwitters, Kristi Dubois, Bert Lindler, Tom Carlsen, and Rick Northrup. Our apologies to those whose names we failed to mention.

Return or colony-size data for the Canyon Ferry, Medicine Lake, and Bowdoin colonies were shared by Tom Carlson, Beth Madden, Dwain Prellwitz, and Jeff Marks, or provided by the U.S.D.I. Bird Banding Laboratory, Laurel, Maryland. Pam Garrettson (USFWS) made a heroic effort to obtain old return location data from Mexico for the Bowdoin colony. Tommy King (USDA National Wildlife Center, Mississippi State, Mississippi) provided the most recent global estimates on the number of breeding colonies.

Cedron Jones and Whitney Weber (both MTNHP) produced the maps. This report benefited from the comments of Tom Carlsen (Canyon Ferry Wildlife Management Area), Dwain Prellwitz (Bowdoin National Wildlife Refuge), Beth Madden (Medicine Lake National Wildlife Refuge), John Carlson (MTNHP), Sue Crispin (MTNHP) and Joy Lewis (MTNHP). Terrie Kenney (MTNHP) provided comments and was invaluable in the final preparation of this report. 


\section{TABLE OF CONTENTS}

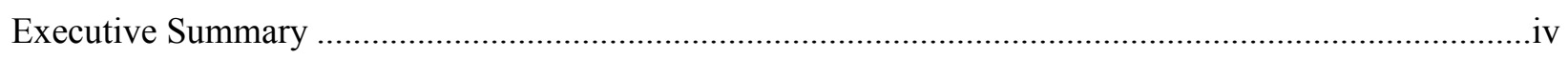

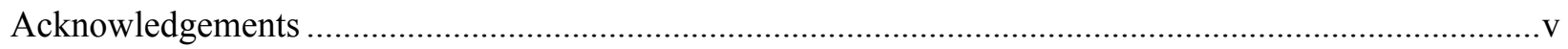

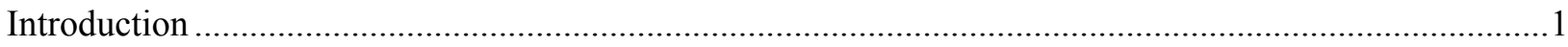

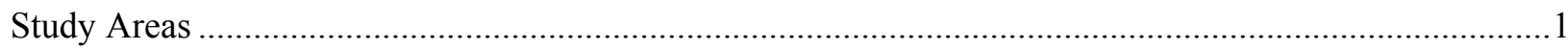

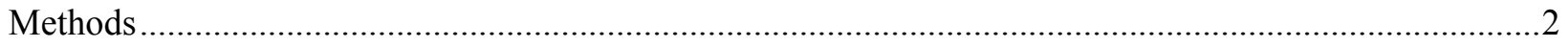

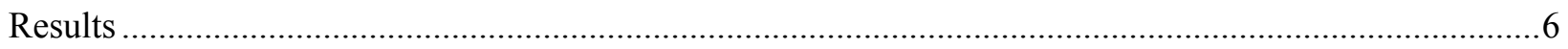

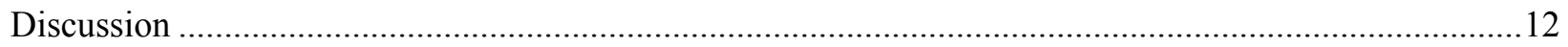

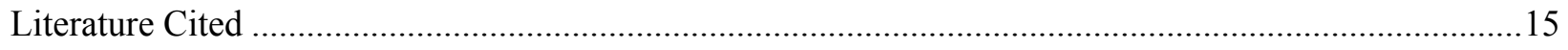

Table 1. Band recovery locations for fledged American White Pelicans banded at three colonies in Montana. Colonies are listed from east to west............................................................................ 7

Table 2. Circumstances associated with bands recovered from fledged American White Pelicans banded at three Montana colonies. Colonies are listed east to west. .........................................................

Table 3. Age distribution of recovered American White Pelicans banded as flightless young at three Montana colonies. Colonies are listed east to west. Year 1 is the first year following banding, and so on. "Band only" recoveries are not included in the calculations.

Table 4. Distribution of band recoveries by age (excluding "band only" returns) for the combined Arod Lake and Canyon Ferry colonies of American White Pelican in Montana. Numbers in bold show the elevated number of recoveries in 1996 for each age class, mostly from the Salton Sea, California...13

Figure 1. Distribution of American White Pelican returns for the Bowdoin Lake colony, Phillips County, Montana. Five of twelve Mexico returns are not shown because specific location data were not available (states of recovery are listed in Table (1).

Figure 2. Distribution of American White Pelican returns for the Canyon Ferry Reservoir colony, Broadwater County, Montana.

Figure 3. Distribution of American White Pelican returns for the Arod Lakes colony, Teton County, Montana.

Figure 4. Seasonal distribution of band returns for immature (A) and adult (B) American White Pelicans from Arod Lakes (open fill), Canyon Ferry (right-diagonal fill), and Bowdoin (cross-hatched fill) colonies. Numbers of band returns are indicated above the bars. 


\section{INTRODUCTION}

The American White Pelican (Pelecanus erythrorhynchos) is widespread throughout much of western and southeastern North America, and is frequently encountered at lakes, reservoirs, rivers, and coastal regions, often in large numbers. Most breeding colonies in Canada and the United States lie west of the Mississippi River and north of $40^{\circ} \mathrm{N}$ latitude (Vermeer 1970, Sidle et al. 1985, Evans and Knopf 1993), with a few isolated colonies in southern Texas and northern Mexico (Chapman 1988, Evans and Knopf 1993). The number of breeding birds for all colonies has exceeded 100,000 in recent decades (Sidle et al. 1985), with an additional unknown number of non-breeding individuals, but the global breeding population is concentrated now in fewer than 50 colonies (T. King personal communication).

Pelicans disperse from colonies following breeding, eventually wintering in two general areas: in the West from central California south to Central America (often along the Pacific Coast), and in the East throughout the southern United States, along the Gulf of Mexico, and throughout much of the interior of Mexico. Pelicans dispersing from colonies east of the Continental Divide migrate primarily southward and eastward to the Gulf of Mexico coast. Birds dispersing from colonies west of the Continental Divide migrate primarily to California and the western coast of Mexico (Behle 1958, Diem and Condon 1967, Strait and Sloan 1975, Vermeer 1977, Ryder 1981, Evans and Knopf 1993, Keith and O'Neill 2000, King and Grewe 2001).

The few American White Pelican colonies in Montana were small in the early decades of the $20^{\text {th }}$ Century (Saunders 1921), and the state was not thought an important breeding ground for pelicans at the time of the first comprehensive status assessment (Thompson 1933). Following Thompson's survey, numbers of breeding birds increased in Montana such that the state was a major breeding area by the time of the next range-wide status assessment in 1964 (Lies and Behle 1966). Montana has remained a significant breeding ground for American White Pelicans through the end of the $20^{\text {th }}$ Century (Sloan 1982, Sidle et al. 1985).

Over the last several decades a few smaller breeding colonies of American White Pelican have formed in eastern Montana, but most of these were abandoned after a year or two of activity. However, two newer colonies have now remained active for over ten continuous years. This study examined these two newer colonies in more detail, emphasizing dispersal/migration of banded fledglings, natal colony fidelity, and mortality of marked young. We compared attributes of these newer colonies with the older Montana colony at Bowdoin National Wildlife Refuge and considered implications for conservation and management of American White Pelican colonies in Montana.

\section{STUDY AREAS}

Montana's four American White Pelican colonies are scattered from near the North Dakota State line to the Rocky Mountain Front, just 60 miles east of the Divide. We compared data from the two westernmost, recently established colonies at Arod Lakes and Canyon Ferry Reservoir with data from the Bowdoin colony in eastern Montana. Analyses of returns for Medicine Lake, the eastern-most colony in Montana (in Sheridan County), will be presented elsewhere (B. Madden, personal communication), and are discussed in this report only in general terms. For migratory patterns and mortality factors, comments pertaining to the Bowdoin colony apply generally to Medicine Lake as well.

Arod (or Eyraud) Lakes: This colony in Teton County (47 59' N, $112^{\circ} 01^{\prime}$ W) was discovered in 1990, when 300 nests were estimated to be present. Since then, nest estimates have varied from 300-500 annually, but no routine counts have been conducted. Annual numbers of young fledged at this colony 
has varied dramatically from about 60 in 2000 to over 700 in 1993. Between 1991-1996, 2220 young were banded, but no additional banding has occurred at this colony since 1996.

Canyon Ferry Reservoir: This colony in Broadwater County ( $\left.46^{\circ} 24^{\prime} \mathrm{N}, 111^{\circ} 30^{\prime} \mathrm{W}\right)$ was discovered in 1989 when 13 nests were counted. It grew dramatically since then to 1804 nests in 2000 . Banding also occurred at this colony during 1991-1996, with 1537 young banded. As with the Arod colony, no banding has occurred at Canyon Ferry since 1996.

Bowdoin Lake: This colony, on a National Wildlife Refuge in Phillips County (48 $24^{\prime}$ N, $107^{\circ} 41^{\prime}$ W), has been known since 1903 when George Willett (1907) reported a small nesting colony on one of the islands in the lake. At least 336 nests were present by 1935 (Weydemeyer and Marsh 1936). Estimates of nest numbers have generally increased since then (Lies and Behle 1966, Sidle et al. 1985), and during the 1990's ranged from 1552 nests in 1999 to 2882 nests in 1993. Banding has occurred intermittently at Bowdoin: 1932-1934, 1936-1940, 1942-1943, 1946-1947, and 1958. No banding has been undertaken at this colony in recent decades.

\section{METHODS}

We obtained band recovery data for the Bowdoin, Canyon Ferry, and Arod Lakes colonies from the Bird Banding Laboratory (BBL) in Laurel, Maryland. Additional reports of banded birds from Arod Lakes and Canyon Ferry Reservoir were made directly to the Montana Natural Heritage Program (MTNHP), which supervised the banding at these two colonies. Our tabular analyses included only recoveries reported through the BBL. We have noted the additional MTNHP reports in the results, however, to supplement BBL data and address specific points.

Distribution maps of band returns were generated from latitude-longitude data (10' blocks) provided by the BBL. Mexico returns for the Bowdoin colony were not portrayed in the distribution map (Figure 1) because data were not provided in latitude-longitude format. Returns from Mexican States are listed in Table 1, however. We define recovery sites west of the Continental Divide as including British Columbia, those states designated by the BBL with the Pacific Flyway code 4 (Washington, Oregon, California, Idaho, Nevada, Utah, and Arizona), all Mexican States bordering the Pacific coast, and Central American locations on the Pacific coast. All other recovery sites are treated as east of the Continental Divide.

All birds were banded with standard aluminum bands while they were flightless juveniles. During the marking program at Arod Lakes and Canyon Ferry Reservoir aluminum bands were supplemented with colored plastic bands (red-Arod, blue-Canyon Ferry); in all, 575 (25.9\%) of 2220 birds at Arod Lakes, and 763 (49.6\%) of 1537 birds at Canyon Ferry Reservoir were color banded. Juveniles considered too small to retain bands were not marked. We revisited one colony each year in 1992-1995 to look for lost bands. Band losses before fledging each year ranged from $0.9-1.3 \%(1.03 \pm 0.19 \%, \mathrm{~N}=4)$.

Circumstances identified with band returns (found dead, shot, etc.) were taken from coded data provided by the BBL. We assigned returns to one of four season categories based on the annual cycle (see Evans and Knopf 1993). Spring (February, March, April) is the season when birds are beginning to move to breeding colonies, summer (May, June, July) is when breeding birds and first-year birds are mostly associated with the breeding colonies, autumn (August, September, October) tends to be the period when birds move to wintering areas, and winter (November, December, January) is the period when birds remain on wintering grounds prior to moving north towards breeding colonies. 


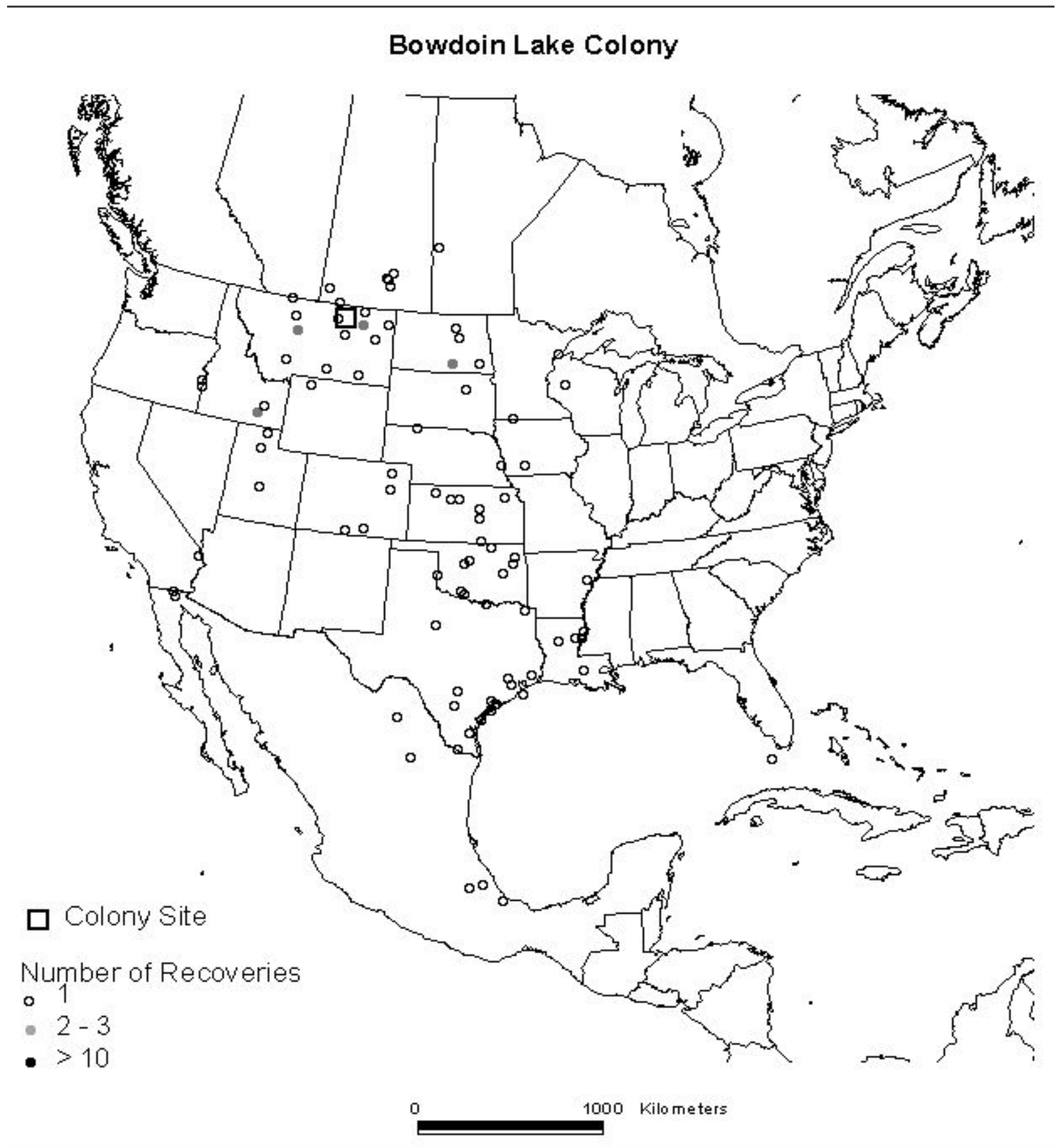

Figure 1. Distribution of American White Pelican returns for the Bowdoin Lake colony, Phillips County, Montana. Five of twelve Mexico returns are not shown because specific location data were not available (states of recovery are listed in Table (1). 


\section{Canyon Ferry Colony}

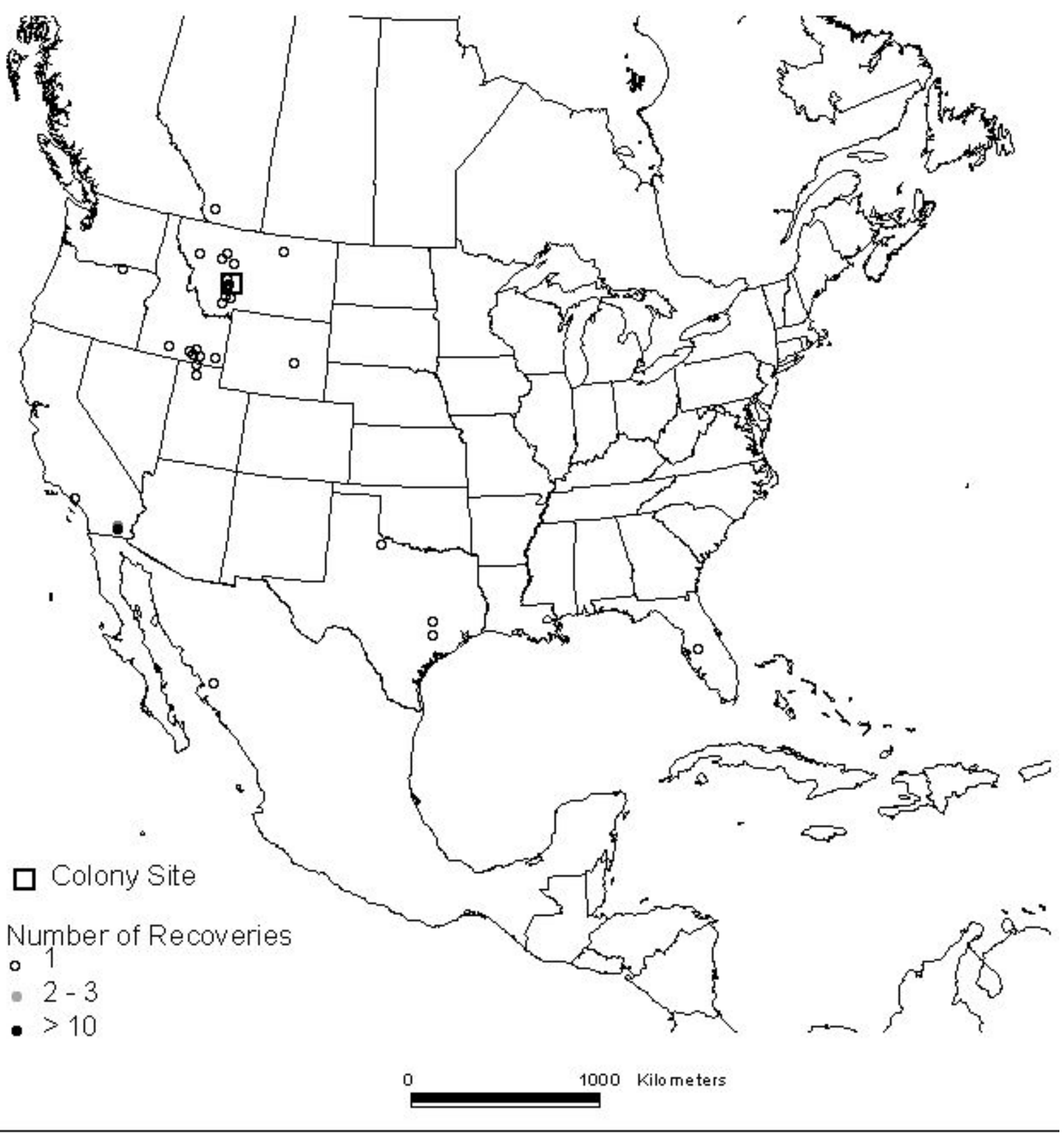

Figure 2. Distribution of American White Pelican returns for the Canyon Ferry Reservoir colony, Broadwater County, Montana. 


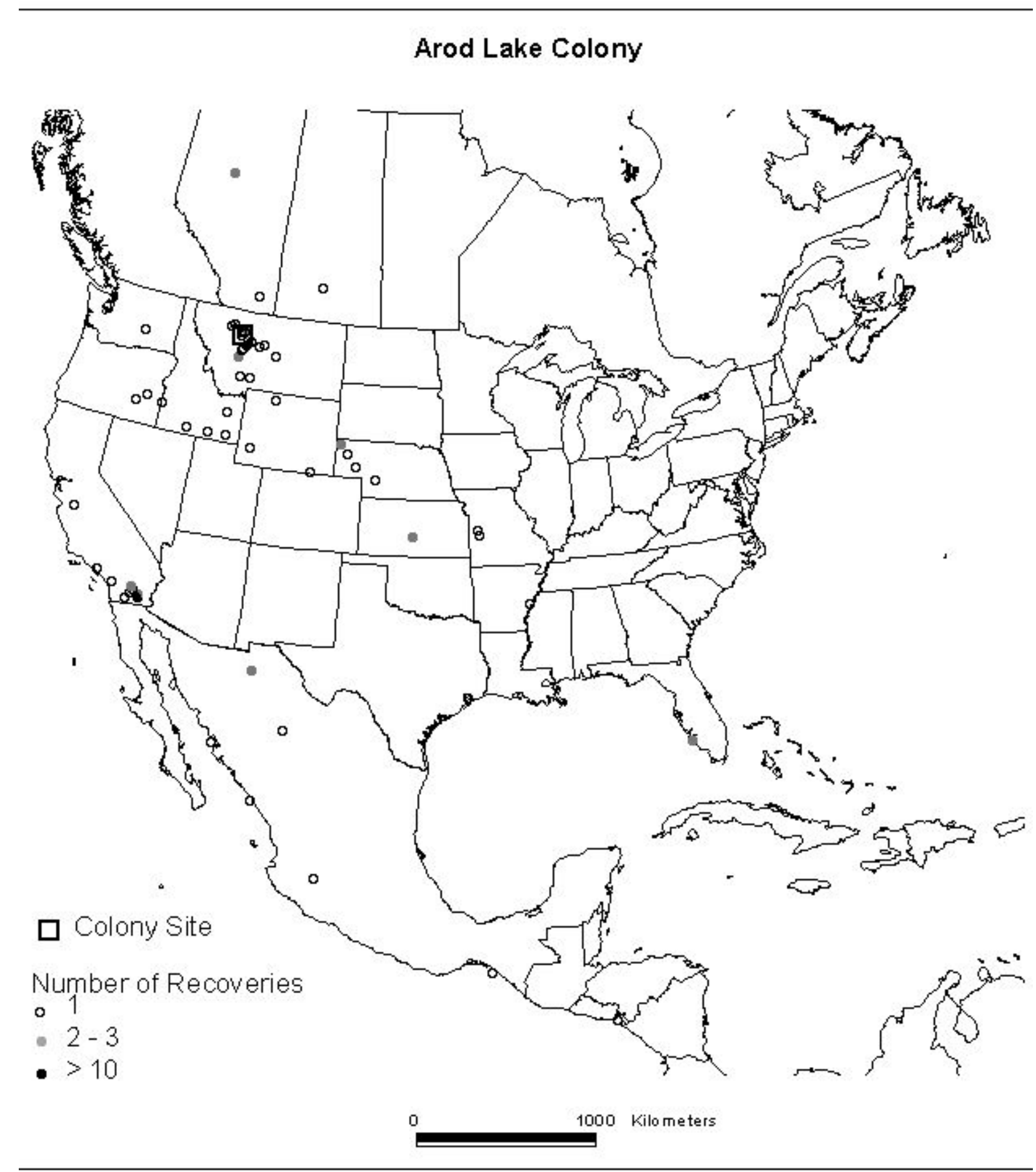

Figure 3. Distribution of American White Pelican returns for the Arod Lakes colony, Teton County, Montana. 
Mortality rates for immature and adult pelicans, and overall colony means, were calculated from composite life tables based on band returns with definite dates of recovery (see Ryder 1981). This method is likely to overestimate true mortality rates (Seber 1972, Botkin and Miller 1974) but is used here for comparisons among colonies. Where we used statistical tests in analyses of frequency distributions of recovery data we followed standard procedures (Sokal and Rohlf 1981).

\section{RESULTS}

Recovery location: The 276 band returns provided by the BBL for the Bowdoin, Canyon Ferry, and Arod Lakes American White Pelican colonies are summarized by geopolitical recovery location in Table 1 and Figs. 1-3. Pelicans banded at these three Montana colonies were reported from $55^{\circ} 50^{\prime} \mathrm{N}$ (Alberta) to $13^{\circ} 10^{\prime} \mathrm{N}$ (Honduras). Recoveries within Montana ranged from 20.3-25.2\% of total returns reported by the BBL for the three colonies. The difference among the three pelican colonies in the proportion of in-state recoveries was not statistically significant $\left(G_{2}=0.562, \mathrm{P}>0.5\right)$.

Out-of-Montana recoveries west of the Continental Divide (Table 1) accounted for $14.0 \%$ of returns for Bowdoin, $87.2 \%$ for Canyon Ferry, and $69.6 \%$ for Arod Lakes. The differences between colonies in proportions of recoveries east and west of the Continental Divide were highly significant $\left(G_{2}=91.390, \mathrm{P}\right.$ $<<0.001$ ), with the fewest western returns for the colony farthest east from the Divide.

For the Arod Lakes and Canyon Ferry colonies, the greatest number of out-of-state returns $(45.1 \%$ and $64.4 \%$, respectively) came from California and Idaho (Table 1). California and Idaho accounted for $<$ $6 \%$ of total recoveries for the Bowdoin colony. By contrast, midwestern and central states (North Dakota, South Dakota, Nebraska, Kansas, Oklahoma and Texas) accounted for 32.2\% of total returns for Bowdoin, but only 5.1\% and 7.8\% for Canyon Ferry and Arod Lakes, respectively. Ten of 12 Mexican recoveries for Bowdoin occurred in states east of the Continental Divide. The opposite pattern was evident for the Canyon Ferry and Arod colonies combined, with $66.7 \%$ (6 of 9) of recoveries from states west of the Continental Divide.

Routes of movement: Recovery locations are plotted on maps for each colony (Figs. 1-3), excluding Mexico recoveries for Bowdoin (see Table 1). These maps suggest the primary routes of migration used by members of each colony.

Bowdoin pelicans apparently moved to the south and east to the Gulf of Mexico, where they spread out along the coast (Fig. 1). They seemed to use a broad migratory pathway west of the Mississippi River to reach the Gulf. The minority that moved west traveled to the Snake River in southern Idaho, and then appeared to move south to the Colorado River and western Mexico.

Canyon Ferry and Arod Lakes pelicans moved mostly south and west (Table 1, Figs. 2-3) to the Snake River in southern Idaho and along some unknown route south to the Pacific coast or the Salton Sea in southern California. Others moved to Oregon and northern California, and may have continued to southern California and western Mexico. Pelicans that moved east from the Canyon Ferry and Arod colonies appeared to pass through Wyoming to the North Platte River and on to the Mississippi River south to the Gulf of Mexico. Some birds appeared to travel south through Kansas, Oklahoma, and east Texas. 
Table 1. Band recovery locations for fledged American White Pelicans banded at three colonies in Montana. Colonies are listed from east to west.

\begin{tabular}{|c|c|c|c|}
\hline \multirow[b]{2}{*}{ Recovery location } & \multicolumn{2}{|c|}{ Colony } & \multirow[b]{2}{*}{ Arod } \\
\hline & Bowdoin & Canyon Ferry & \\
\hline \multicolumn{4}{|l|}{ Canada } \\
\hline Alberta & 2 & 1 & 3 \\
\hline Manitoba & 1 & --- & --- \\
\hline Saskatchewan & 6 & --- & 1 \\
\hline \multicolumn{4}{|c|}{ United States (E of Divide) } \\
\hline Arkansas & 1 & --- & 1 \\
\hline Colorado & 4 & --- & --- \\
\hline Florida & 1 & 1 & 2 \\
\hline Iowa & 1 & --- & --- \\
\hline Kansas & 7 & --- & 2 \\
\hline Louisiana & 6 & --- & --- \\
\hline Minnesota & 3 & --- & --- \\
\hline Missouri & --- & --- & 2 \\
\hline Montana & 29 & 12 & 23 \\
\hline Nebraska & 1 & --- & 5 \\
\hline North Dakota & 4 & --- & --- \\
\hline Oklahoma & 9 & --- & --- \\
\hline South Dakota & 2 & --- & --- \\
\hline Texas & 14 & 3 & 1 \\
\hline Wisconsin & 1 & --- & --- \\
\hline Wyoming & 1 & 1 & 4 \\
\hline \multicolumn{4}{|c|}{ United States (W of Divide) } \\
\hline California & 1 & 31 & 41 \\
\hline Idaho & 5 & 7 & 5 \\
\hline Oregon & 1 & 1 & 2 \\
\hline Utah & 3 & 1 & --- \\
\hline Washington & --- & --- & 1 \\
\hline \multicolumn{4}{|c|}{ Mexico (E of Divide) } \\
\hline Chihuahua & --- & --- & 3 \\
\hline Coahuila & 1 & --- & --- \\
\hline Mexico & 1 & --- & --- \\
\hline Nuevo Leon & 1 & -- & --- \\
\hline Puebla & 2 & --- & --- \\
\hline Tamaulipas & 2 & --- & --- \\
\hline Vera Cruz & 3 & --- & --- \\
\hline \multicolumn{4}{|c|}{ Mexico (W of Divide) } \\
\hline Baja California & 2 & --- & --- \\
\hline Chiapas & --- & --- & 1 \\
\hline Jalisco & --- & --- & 1 \\
\hline Sinaloa & --- & 1 & 3 \\
\hline \multicolumn{4}{|l|}{ Central America } \\
\hline Honduras & --- & --- & 1 \\
\hline Total recoveries & 115 & 59 & 102 \\
\hline
\end{tabular}


The Salton Sea was a particularly important wintering area for American White Pelicans from the Canyon Ferry and Arod colonies. Forty-one percent of 161 band recoveries for the two colonies (66 total: 30 from Canyon Ferry and 36 from Arod Lakes) were reported from the Salton Sea, representing all cohorts (1991-1996) from each colony.

Some pelicans from each of the Montana colonies moved north into adjacent Canadian provinces (Table 1, Figs. 1-3). The routes followed and time of year when birds first dispersed northward is uncertain. The location of recoveries suggested that many birds did not follow river corridors. Two $(15.4 \%)$ of 13 recoveries from this group (one "band only") were for first year birds, both recovered in September. Other recoveries in Canada were usually from late spring and summer; ages of these birds ranged from $3-9$ years $(5.4 \pm 2.2$ years, $\mathrm{N}=11)$.

Fidelity to natal colony: There are few data on natal colony fidelity for two of the Montana colonies. Recoveries at natal colonies (not including first-year juveniles and "band only" returns) totaled six birds at Bowdoin (ages 2, 2, 4, 5, 6, 9) and three birds at Canyon Ferry (ages 2, 4, 7).

The Arod Lakes colony was searched for banded birds several times by volunteer observers and MTNHP personnel, who reported 15 third-year birds, 9 fourth-year birds, 5 fifth-year birds, 3 seventh-year birds, and 1 eighth-year bird. Of these, 14 third-year and 6 fourth-year birds were killed in 1997 by a latesummer hailstorm (J. and D. Rhinehart, personal communication).

In-state band recoveries for birds that moved between colonies were rare. The band of one bird marked at Medicine Lake in 1967 was found at Bowdoin in 1983 (B. Madden personal communication). A sixth-year bird banded at Bowdoin was found dead following a storm in July 1942 at Medicine Lake. Birds banded at Bowdoin or Medicine Lake have yet to be reported at Canyon Ferry or Arod Lakes, but banding ceased at these two eastern colonies well before the western colonies were founded, so this result is expected.

Of more than 3500 birds banded at Canyon Ferry and Arod Lakes during 1991-1996, only one has been reported from the two older colonies in eastern Montana, and only two others have been reported moving between the two newer colonies. One sixth-year bird from Canyon Ferry was found dead at Bowdoin in August 1998, and one fourth-year bird was observed paired in May 2000 at Arod Lakes. One sixth-year bird from Arod Lakes was found injured in September 1997 at Canyon Ferry.

Circumstance of recoveries: Most of the returns from Bowdoin and Arod were from birds "found dead"-- 53.0\% and 42.2\%, respectively (Table 2). For Canyon Ferry, 39.0\% of all returns were from birds found dead. Proportions of birds found dead (excluding band-only returns) differed significantly among colonies $\left(G_{2}=6.142, \mathrm{P}<0.05\right)$ but remain a substantial unknown in the analysis of mortality for all Montana colonies. Shooting and disease were the second most frequently identified causes of band recovery across all colonies. Shot pelicans represented $21.7 \%$ of recoveries for Bowdoin, but only $0.0 \%$ and $2.0 \%$ of recoveries for Canyon Ferry and Arod Lakes, respectively. Disease accounted for $47.5 \%$ and $34.3 \%$ of returns for the Canyon Ferry and Arod colonies, respectively, but was undocumented among Bowdoin returns. Rates of shooting and disease returns (excluding band-only) differed very significantly between colonies $\left(G_{4}=105.932, \mathrm{P}<<0.001\right)$. The three mortality "factors" combined (found dead, shot, and disease) accounted for $74.8-86.4 \%$ of the total recoveries for the three Montana colonies $\left(G_{2}=3.358, \mathrm{P}>0.1\right)$. 
Table 2. Circumstances associated with bands recovered from fledged American White Pelicans banded at three Montana colonies. Colonies are listed east to west.

\begin{tabular}{lccc}
\hline Recovery circumstance & Bowdoin & $\begin{array}{c}\text { Colony } \\
\text { Canyon Ferry }\end{array}$ & Arod \\
\hline Found dead & & & 43 \\
Shot & 61 & 23 & 2 \\
Disease & 25 & --- & 35 \\
Injured & --- & 28 & 4 \\
Caught & 8 & 1 & 2 \\
Weather & --- & --- & -- \\
Entangled & 7 & 1 & 2 \\
Collision & 2 & --- & 5 \\
Band only & 1 & 3 & 7 \\
Sight record & 11 & 1 & 102 \\
\hline Total recoveries & --- & & 59 \\
\hline
\end{tabular}

Mortality rates and age distribution of recoveries: Age of recovery for Montana pelicans from the three colonies (Table 3) ranged from 1-20 years; the oldest bird was from Bowdoin. Adult mortality rates ranged from $23.0 \%$ at Bowdoin to $57.6 \%$ at Arod (Canyon Ferry was 36.5\%). Overall mean annual mortality rates ranged from $29.9 \%$ at Canyon Ferry to $39.3 \%$ at Arod (Bowdoin was $30.0 \%$ ). The adult estimates for Arod and Canyon Ferry are unusually high for this species (see Ryder 1981, Evans and Knopf 1993), as is the overall estimate for Arod.

Table 3. Age distribution of recovered American White Pelicans banded as flightless young at three Montana colonies. Colonies are listed east to west. Year 1 is the first year following banding, and so on. "Band only" recoveries are not included in the calculations.

\begin{tabular}{|c|c|c|c|}
\hline \multirow[b]{2}{*}{ Year } & \multicolumn{2}{|c|}{ Colony } & \multirow[b]{2}{*}{ Arod } \\
\hline & Bowdoin & Canyon Ferry & \\
\hline 1 & $50.0 \%(52)$ & $21.4 \%(12)$ & $38.1 \%(37)$ \\
\hline 2 & $7.7 \%(8)$ & $23.2 \%(13)$ & $18.6 \%(18)$ \\
\hline 3 & $6.7 \%(7)$ & $8.9 \%(5)$ & $12.4 \%(12)$ \\
\hline 4 & $3.8 \%(4)$ & $21.4 \%(12)$ & $15.5 \%(15)$ \\
\hline 5 & $8.7 \%(9)$ & $7.1 \%(4)$ & $8.2 \%(8)$ \\
\hline 6 & $7.7 \%(8)$ & $12.5 \%(7)$ & $5.2 \%(5)$ \\
\hline 7 & $2.9 \%(3)$ & $3.6 \%(2)$ & $1.0 \%(1)$ \\
\hline 8 & --- & $1.8 \%(1)$ & $1.0 \%(1)$ \\
\hline 9 & $8.7 \%(9)$ & --- & --- \\
\hline 10 & --- & --- & --- \\
\hline 11 & $1.9 \%(2)$ & --- & --- \\
\hline 12 & $1.0 \%$ & --- & --- \\
\hline$>12$ & $1.0 \%$ & --- & --- \\
\hline Total recoveries & 104 & 56 & 97 \\
\hline
\end{tabular}


The majority of band recoveries from Bowdoin and Arod were for birds of all ages "found dead" of unknown causes (Table 2). Typical for pelicans (Sloan 1982, Evans and Knopf 1993) about half of the recoveries for each colony, excluding "band only" returns, were immatures (birds $<3$ years). Annual mortality rates of immature pelicans ranged from $24.2 \%$ at Canyon Ferry to $38.5 \%$ at Bowdoin (Arod was $35.4 \%$ ). Immature (first- and second-year) birds comprised the majority shot. Nearly two thirds of shot birds from Bowdoin were immatures. Both of the shot pelicans from the Arod colony were secondyear immatures; there were no recoveries from Canyon Ferry linked to shooting.

Pelicans of all ages appeared equally susceptible to botulism. Large proportions (two thirds or more) of second- and fourth-year birds in recoveries from the Canyon Ferry colony (Table 3) were related to a botulism outbreak in the Salton Sea, California. Similar peaks in recoveries of these two age groups from the Arod colony were evident, and attributable to the same botulism outbreak in 1996.

Furthermore, disease contributed to increased mortality in each cohort (Table 4).

Pooled recovery data for the Canyon Ferry and Arod colonies showed a noticeable pattern in peak recoveries for each age class, beginning with first-year returns in the 1996 cohort (15 returns) and running diagonally through the data matrix in Table 4 to the upper right (bold numbers), ending with sixth-year birds of the 1991 cohort (4 returns). Botulism-related recoveries at Salton Sea for the six cohorts (1991-1996) accounted for 55 of 76 post-July returns in 1996. Percentage of returns attributed to botulism were $67 \%$ of first-year 1996 birds, $83 \%$ of second-year 1995 birds, $86 \%$ of third-year 1994 birds, 85\% of fourth-year 1993 birds, 71\% of fifth-year 1992 birds, and 100\% of sixth-year 1991 birds.

Season of recovery: Over half of the band returns for the three colonies combined (not including "band only" returns) occurred in autumn (Fig. 4). This pattern was evident for immature pelicans (Fig. 4a), with no significant difference in the seasonal distribution of returns for the three colonies $\left(G_{6}=1.114, \mathrm{P}\right.$ $>0.9$ ). Adult returns for the Arod and Canyon Ferry colonies also showed an autumn peak in returns similar to the pattern for immatures (Fig. 4b). Bowdoin, however, showed equal proportions of adult returns for all seasons, in contrast to the other two colonies $\left(G_{3}=24.036, \mathrm{P}<0.001\right.$; Arod and Canyon Ferry pooled). The difference in seasonal distribution of adult recoveries was probably related to disease-caused mortality of migrant and wintering Arod and Canyon Ferry pelicans at the Salton Sea. 

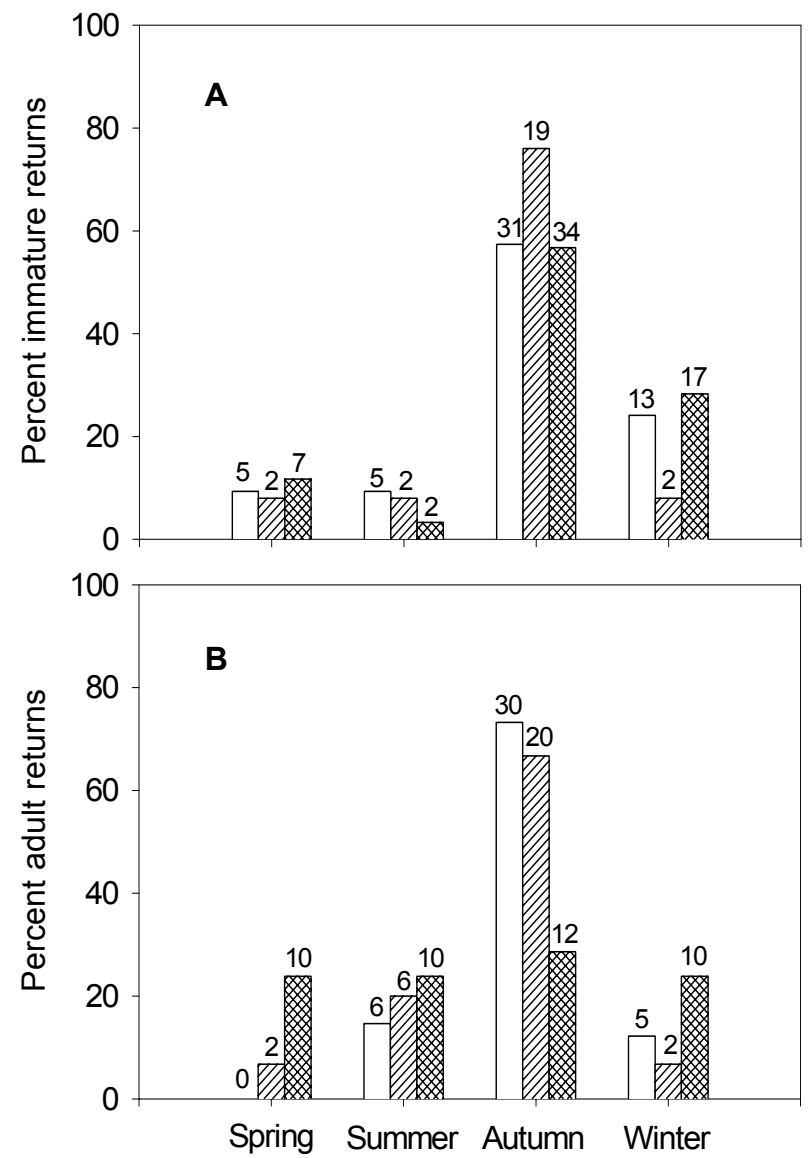

Figure 4. Seasonal distribution of band returns for immature (A) and adult (B) American White Pelicans from Arod Lakes (open fill), Canyon Ferry (right-diagonal fill), and Bowdoin (crosshatched fill) colonies. Numbers of band returns are indicated above the bars. 


\section{DISCUSSION}

Colony isolation and flyway affiliation: Data gathered from juvenile American White Pelicans banded at the Bowdoin, Canyon Ferry, and Arod colonies suggest that migratory movements fall into two groupings. Birds from the westernmost colonies (Canyon Ferry, Arod Lakes) migrate largely west across the Continental Divide via Idaho to southern California and western Mexico. Birds from the eastern colony (Bowdoin) migrate largely south and east along the Missouri and Mississippi rivers, or through the Midwest, to the Gulf of Mexico and eastern Mexico. The Medicine Lake colony follows the Bowdoin pattern of dispersal (B. Madden personal communication).

The two western-most American White Pelican colonies in Montana (Canyon Ferry and Arod Lakes) are functionally a part of the Intermountain West and Pacific flyways, which include colonies in British Columbia, Utah, Oregon, Nevada, California, and Wyoming (see Behle 1958, Diem and Condon 1967, Vermeer 1977, Keith and O'Neill 2000). The two eastern-most pelican colonies in Montana (Bowdoin and Medicine Lake) are functionally a part of the Central and Mississippi flyways (see Strait and Sloan 1975, Vermeer 1977, Ryder 1981), where the global majority of American White Pelican colonies occur in the upper Midwest and northern Great Plains.

While the recovery data indicate ample opportunity for in-state immigration among Montana pelican colonies, documented cases are extremely rare. There are only two records of colony exchange between Bowdoin and Medicine Lake, separated by $250 \mathrm{~km}$, and only two records of colony exchange between Canyon Ferry and Arod Lakes, located about $200 \mathrm{~km}$ apart. Because many pelicans were color-marked at these latter two colonies, increasing the probability of documenting inter-colony movements, we would expect more records of inter-colony exchange if it were occurring with any regularity. There is also only one report of a pelican from one colony group appearing in the other (a Canyon Ferry bird reported at Bowdoin). This suggests that each colony is relatively isolated reproductively despite their close proximity and the dispersal capabilities of the birds.

Two other factors may account for the apparent rarity of inter-colony movements. First, there has been no banding at the eastern colonies since the western colonies became established. Second, colony surveys are not routinely conducted during the pre- and post-breeding periods, thereby reducing the likelihood of observing banded pelicans or recovering their remains.

The two colony groups in Montana may represent parts of two larger metapopulations (Hanski 1996), with occasional immigration and emigration among other colonies along the migration routes of the Montana birds. Little hard data exists showing such a reproductive connection between the various colonies during the breeding season, although a few pelicans from Montana have been recovered in summer from colonies in other states and provinces. Nevertheless, pelicans establish new colonies and reestablish old ones (Sloan 1982, Findholt and Diem 1988, Paullin et al. 1988, Bryan 1991). The natal pelican colony for the founders of the Arod and Canyon Ferry colonies is unknown; migratory behavior of birds from these two western Montana colonies indicates the founders probably were birds with ties to colonies in states west of the Continental Divide. 
Table 4. Distribution of band recoveries by age (excluding "band only" returns) for the combined Arod Lake and Canyon Ferry colonies of American White Pelican in Montana. Numbers in bold show the elevated number of recoveries in 1996 for each age class, mostly from the Salton Sea, California.

\begin{tabular}{|c|c|c|c|c|c|c|c|c|c|c|c|}
\hline \multirow{2}{*}{$\begin{array}{c}\text { Year } \\
\text { banded }\end{array}$} & \multirow{2}{*}{$\begin{array}{c}\text { No. } \\
\text { banded }\end{array}$} & \multirow[b]{2}{*}{1} & \multicolumn{6}{|c|}{ Year of recovery after banding } & \multicolumn{3}{|c|}{ Total } \\
\hline & & & 2 & 3 & 4 & 5 & 6 & 7 & 8 & returns & $\%$ \\
\hline 1991 & 200 & 2 & --- & --- & --- & --- & 4 & --- & --- & 6 & 3.0 \\
\hline 1992 & 668 & 10 & 1 & 2 & 1 & 7 & 1 & 1 & 1 & 24 & 3.6 \\
\hline 1993 & 1059 & 10 & 2 & 4 & 20 & 1 & 4 & 2 & 1 & 44 & 4.2 \\
\hline 1994 & 668 & 4 & 4 & 7 & --- & 1 & 1 & --- & --- & 17 & 2.5 \\
\hline 1995 & 791 & 8 & 23 & 2 & 5 & 1 & 2 & --- & --- & 41 & 5.2 \\
\hline 1996 & 371 & 15 & 1 & 2 & 1 & 2 & --- & --- & --- & 21 & 5.7 \\
\hline Total & 3757 & 49 & 31 & 17 & 27 & 12 & 12 & 3 & 2 & 154 & 4.1 \\
\hline
\end{tabular}

Implications for management: Conservation of American White Pelican populations requires coordinated management at widely separated breeding and wintering sites. Pelicans from the Arod and Canyon Ferry colonies in Montana clearly are linked to wintering sites in California. Botulism outbreaks in the Salton Sea of southern California could significantly affect adult survivorship of the two Montana colonies (Fig. 4, Tables 2 and 4) as well as other western colonies (Cohn 2000). All age classes of pelicans from the Arod Lakes and Canyon Ferry colonies (Tables 3-4 and their interpretation) were affected by the 1996 botulism outbreak at the Salton Sea; catastrophic events of this magnitude could alter the age-structure of the breeding membership at each colony. Because the Salton Sea is likely to undergo massive changes in the $21^{\text {st }}$ century (Jehl 1994), the results of future management activities at this site will be of importance to the pelicans of the western colonies in Montana. The Snake River in southern Idaho is another important stopping spot in the non-breeding season for members of these two colonies (Table 1, Figs. 2-3) experiencing increased pressure from human recreation and agriculture that could negatively affect pelican use (personal observation).

The Bowdoin and Medicine Lake colonies are clearly linked primarily to coastal wintering sites along and near the Gulf of Mexico, rather than the Salton Sea and other saline lakes of the Great Basin. Shooting in former decades, mostly of immature birds in migration and at wintering sites, was a significant mortality factor for the membership of the Bowdoin colony (Table 2), and Medicine Lake as well (B. Madden personal communication). Similar mortality from shooting in former decades has also been documented for other eastern colonies such as Chase Lake, North Dakota (Strait and Sloan 1975), and Riverside Reservoir, Colorado (Ryder 1981); at Marsh Lake, Minnesota, where banding was begun more recently than at Chase Lake and Riverside Reservoir, shooting mortality was responsible for a smaller percentage of returns, but most of these came from Mexico and Central America where enforcement of protection may be more difficult to implement (King and Grewe 2001).

Whether shooting remains a major contributor to mortality is unknown; protection for pelicans has increased in recent decades, but concurrent band return data are usually not available. Data from the Arod and Canyon Ferry colonies suggest shooting is not a serious threat, at least north of Mexico, but this could be due to their migratory routes in the Intermountain West and Pacific flyways rather than a range-wide decline in shooting mortality. In addition, the preponderance of "found dead" returns for all Montana colonies could include a significant number of shot birds reported as "found dead" to avoid prosecution (King and Grewe 2001). One newer threat for pelicans wintering in the Gulf Coast states (which includes the Bowdoin and Medicine Lake birds) is a rapidly expanding catfish aquaculture 
industry. There are increasing numbers of pelicans foraging and loafing near these aquaculture facilities (King and Grewe 2001) that likely will result in more human-pelican conflicts and the possible implementation of lethal measures to control pelican depredation.

In conclusion, we concur with Parnell et al. (1988) that management of pelican colonies involves more than just the colony itself, although events at individual colonies remain extremely important in determining year-to-year viability; Montana pelicans experienced significant declines in the 1960's and 1970's due to water level fluctuations at their breeding colonies (Sloan 1982). However, because most colonies are probably dependent on larger regional populations, effective management needs to address factors that affect recruitment of sub-adults into breeding populations throughout regional landscapes.

A coordinated color-marking program at each of the Montana colonies, with routine pre-and postbreeding surveys for marked birds could clarify the isolation of the two colony groupings, the degree of dispersal among the individual colonies within each grouping, and better document colony dispersal during the non-breeding season. Similar marking and monitoring programs would yield valuable data for breeding colonies in other regions.

The results of this and further studies would help in developing regional management plans that 1) identify current and impending threats to breeding and wintering populations linked through dispersal, 2) provide for coordinated responses to those threats, and 3) support the maintenance of viable populations of American White Pelicans throughout their range. 


\section{Literature Cited}

Behle, W. H. 1958. The bird life of Great Salt Lake. University of Utah Press. Salt Lake City, UT. $230 \mathrm{pp}$.

Botkin, D. B., and R. S. Miller. 1974. Mortality rates and survival of birds. American Naturalist 108:181-192.

Bryan, S. 1991. Pelicans nesting on Lake Nipigon. Ontario Birds 9:58-63.

Chapman, B. R. 1988. History of the White Pelican colonies in south Texas and northern Tamaulipas. Colonial Waterbirds 11:275-283.

Cohn, J. P. 2000. Saving the Salton Sea. BioScience 50:295-301.

Diem, K. L., and D. D. Condon. 1967. Banding studies of water birds on the Molly Islands, Yellowstone Lake, Wyoming. Yellowstone Library and Museum Association. Yellowstone National Park, WY. 41 pp.

Evans, R. M, and F. L. Knopf. 1993. American White Pelican (Pelecanus erythrorhynchos). In The Birds of North America, No. 57 (A. Poole and F. Gill, Eds.). Philadelphia: The Academy of Natural Sciences; Washington, D.C.: The American Ornithologists' Union. 24 pp.

Findholt, S. L., and K. L. Diem. 1988. Status and distribution of American White Pelican nesting colonies in Wyoming: an update. Great Basin Naturalist 48:285-289.

Hanski, I. 1996. Metapopulation ecology. Pp. 13-43 In Population dynamics in ecological space and time (O. E. Rhodes, Jr., R. K. Chesser, and M. H. Smith, eds.). University of Chicago Press, Chicago, IL.

Jehl, J. R., Jr. 1994. Changes in saline and alkaline lake avifaunas in western North America in the past 150 years. Studies in Avian Biology 15:258-272.

Keith, J. O., and E. J. O’Neill. 2000. Movements of juvenile American White Pelicans from breeding colonies in California and Nevada. Waterbirds 23:33-37.

King, D. T., and A. H. Grewe, Jr. 2001. Movements and mortality of American White Pelicans banded at Marsh Lake, Minnesota. North American Bird Bander 26:57-60.

Lies, M. F., and W. H. Behle. 1966. Status of the White Pelican in the United States and Canada through 1964. Condor 68:279-292.

Parnell, J. F., D. G. Ainley, H. Blokpoel, B. Cain, T. W. Custer, J. L. Dusi, S. Kress, J. A. Kushlan, W. E. Southern, L. E. Stenzel, and B. C. Thompson. 1988. Colonial waterbird management in North America. Colonial Waterbirds 11:129-169.

Paullin, D. G., G. L. Ivey, and C. D. Littlefield. 1988. The re-establishment of American White Pelican nesting in the Malheur-Harney Lakes Basin, Oregon. Murrelet 69:61-64. 
Ryder, R. A. 1981. Movements and mortality of White Pelicans fledged in Colorado. Colonial Waterbirds 4:72-76.

Saunders, A. A. 1921. A distributional list of the birds of Montana. Pacific Coast Avifauna Number 14. $194 \mathrm{pp}$.

Seber, G. A. F. 1972. Estimating survival rates from bird-band returns. Journal of Wildlife Management 36:405-413.

Sidle, J. G., W. H. Koonz, and K. Roney. 1985. Status of the American White Pelican: an update. American Birds 39:859-864.

Sloan, N. F. 1982. Status of breeding colonies of White Pelicans in the United States through 1979. American Birds 36:250-254.

Sokal, R. R., and F. J. Rohlf. 1981. Biometry, second edition. W. H. Freeman and Company. San Francisco, CA. 859 pp.

Strait, L. E., and N. F. Sloan. 1975. Movements and mortality of juvenile White Pelicans from North Dakota. Wilson Bulletin 87:54-59.

Thompson, B. H. 1933. History and present status of the breeding colonies of the White Pelican (Pelecanus erythrorhynchos). National Park Service, Contribution of the Wildlife Division, Occasional Paper No. 1. 85 pp.

Vermeer, K. 1970. Distribution and size of colonies of White Pelicans, Pelecanus erythrorhynchos, in Canada. Canadian Journal of Zoology 48:1029-1032.

Vermeer, K. 1977. Comparison of White Pelican recoveries from colonies east and west of the Canadian Rocky Mountains. Murrelet 58:79-82.

Weydemeyer, W., and V. L. Marsh. 1936. The bird life of Lake Bowdoin, Montana. Condor 38:185198.

Willett, G. 1907. Summer birds of a prairie lake. Condor 9:105-106. 